naire was used. We checked the validity of this shortened scale by applying it together with the Jenkins activity survey type A scale in another sample of 99 men in the same area. The Spearman correlation coefficient between the two scores within the same men was $r=0.43$, which is closely similar to correlations ${ }^{1}$ using the full Framingham and Jenkins activity survey scales. Secondly, angina was diagnosed only by questionnaire. While any questionnaire may produce some false positive diagnoses, the one used in this study does predict mortality from ischaemic heart disease. ${ }^{3}$ Thirdly, unemployed men were excluded. Certainly employed and unemployed groups cannot be assumed to be comparable, but how this problem has been treated previously is not clear. As most type A instruments refer frequently to work, and the behaviour pattern is believed to occur mostly at work, the validity of type A measurements in the unemployed must be questioned.

A further limitation, which arises in all cross sectional studies of ischaemic heart disease, is that subjects with evidence of disease represent survivors. This raises the problem of interpreting the observed relation of type A solely with angina. Although the number of infarcts recorded was small $(n=10)$, the number of subjects with electrocardiographic evidence of ischaemia was considerable $(n=65)$, and neither showed a relation with type A behaviour. Although studies in the United States ${ }^{1}$ have disclosed an association with electrocardio- graphic evidence of ischaemia as well as infarction and angina, our findings are consistent with those of other European studies. ${ }^{5}$ It may be that the experience of angina increases awareness of ischaemic heart disease and inflates the type A score. Clearly this issue can be settled only by prospective data.

1 Matthews KA. Psychological perspectives on the type A behavior pattern. Psychol Bull 1982;91:293-323

2 Yarnell JWG, Fehily AM, Milbank J, Kubicki AJ, Eastham R, Hayes TH Determinants of plasma lipoproteins and coagulation factors in men from Caerphilly, south Wales. F Epidemiol Community Health 1983;37:137-40.

3 Rose G, Hamilton PSJ, Keen H, Reid DD, McCartney P, Jarrett RJ. Myocardial ischaemia, risk factors and death from coronary heart disease. Lancet $1977 ; \mathrm{i}$ :

4 Appels $\dot{A}$, de Haes $W$, Schuurman J. Een test ter meting van het "coronary-prone behaviour pattern" type A. Nederlands tijdschrift voor psychologie en haar

5 Kornitzer M, Kittel F, de Backer G, Dramaix M. The Belgian heart disease prevention project: type $A$ behavior pattern and the prevalence of coronary heart disease. Psychosom Med 1981;43:133-45.

(Accepted 17 fuly 1984)

MRC Epidemiology Unit (South Wales), Cardiff CF2 3AS

J E J GALLACHER, BSC, attached worker

J W G YARNELL, MD, MFCM, member of scientific staff

P C ELWOOD, MD, FRCP, director

KARIN M PHILLIPS, BSC, member of scientific staff

Correspondence to: $\mathrm{Mr}$ J E J Gallacher.

\section{Haemoglobin A1c concentrations in men and women with diabetes}

Measurement of glycosylated haemoglobin $\mathrm{HbA}_{1 \mathrm{c}}$ concentrations is becoming more common in diabetic clinics as an assessment of long term blood glucose control. We therefore report a recent study in a large diabetic clinic population in which we observed a significant difference in concentrations of $\mathrm{HbA}_{1 \mathrm{c}}$ between men and women.

\section{Subjects, methods, and results}

The study population comprised 909 diabetics ( 430 men, 479 women) and 70 non-diabetic patients ( 35 men, 35 women). HbA $_{1 \mathrm{c}}$ concentrations were measured by isoelectric focusing, ${ }^{1}$ which gave an interassay coefficient of variation of $3.0 \%$ and an intra-assay coefficient of variation of $2 \cdot 6 \%$. Results adopting "acceptable" values in assessing long term blood glucose control. Other workers have also suggested that there may be a difference in $\mathrm{HbA}_{1 \mathrm{c}}$ values between men and women diabetic patients, but numbers were small and there was no indication of the blood glucose concentrations at the time. ${ }^{2}$

The reason for this sex difference is not clear. As $\mathrm{HbA}_{1 \mathrm{c}}$ values are expressed as a percentage of the total haemoglobin concentration of the sample, the known sex difference in total haemoglobin should not affect the result. Chronic blood loss-for example, menstruationand the known sex difference in life span of erythrocytes (men 120 days, women 109 days) would be expected to reduce $\mathrm{HbA}_{1 \mathrm{c}}$ values in women patients rather than increase them. Subdividing men and women patients by other criteria-for example, treatment-had no effect on the result, and no significant difference in mean blood glucose concentrations was observed in any of the subgroups. This indicates that in general women diabetic patients do not have higher

$H b A_{1 c}$ and whole blood glucose concentrations in 979 diabetic and non-diabetic men and women. Results expressed as means ( $S D$ in parentheses)

\begin{tabular}{|c|c|c|c|c|c|c|}
\hline & \multicolumn{3}{|c|}{ Men } & \multicolumn{3}{|c|}{ Women } \\
\hline & No & $\mathbf{H b A}_{1 \mathrm{c}}(\%)$ & $\begin{array}{l}\text { Whole blood } \\
\text { glucose } \\
\text { (mmol/1) }\end{array}$ & No & $\mathbf{H b A}_{1 \mathrm{c}}(\%)$ & $\begin{array}{l}\text { Whole blood } \\
\text { glucose } \\
\text { (mmol/1) }\end{array}$ \\
\hline $\begin{array}{l}\text { Diabetic patients } \\
\text { Non-diabetic patients } \\
\text { Aged } 40 \text { years or less } \\
\text { Aged } 50 \text { years or more } \\
\text { Patients receiving insulin } \\
\text { Non-insulin requiring patients }\end{array}$ & $\begin{array}{r}430 \\
35 \\
105 \\
268 \\
218 \\
212\end{array}$ & $\begin{array}{c}9.6(1.82) * \\
6.6(0.43) \\
9.6(1.66) * \\
9.6(1.94)^{*} \\
10.0(1.75)^{*} \\
9.3(1.82)^{*}\end{array}$ & $\begin{array}{r}9 \cdot 7(3 \cdot 88) \\
9 \cdot 9(4 \cdot 68) \\
9 \cdot 6(3.54) \\
10 \cdot 3(4 \cdot 48) \\
9 \cdot 1(3.03)\end{array}$ & $\begin{array}{r}479 \\
35 \\
98 \\
329 \\
227 \\
252\end{array}$ & $\begin{array}{l}10 \cdot 5(2 \cdot 00) \\
6 \cdot 4(0.46) \\
11 \cdot 1(1.97) \\
10 \cdot 3(2.02) \\
11 \cdot 0(1.76) \\
10.0(2 \cdot 09)\end{array}$ & $\begin{array}{c}9 \cdot 9(4 \cdot 38) \\
10 \cdot 0(4 \cdot 69) \\
9 \cdot 8(4 \cdot 25) \\
10 \cdot 6(4 \cdot 84) \\
9 \cdot 2(3 \cdot 81)\end{array}$ \\
\hline
\end{tabular}

Significantly different from value in women $(\mathrm{p}<0.001)$

Conversion: SI to traditional units-Glucose: $1 \mathrm{mmol} / \mathrm{l} \approx 18 \mathrm{mg} / 100 \mathrm{ml}$.

were expressed as a percentage of the total haemoglobin of the blood sample. Whole blood glucose was measured on a glucose analyser (Yellow Springs).

$\mathrm{HbA}_{1 \mathrm{c}}$ concentrations differed by roughly $9 \%$ between the men and women diabetic patients $(p<0.001$; see table). There was no significant difference in blood glucose concentrations between the sexes, however, nor was there a significant difference in $\mathrm{HbA}_{1}$ values between non-diabetic men and women (table). The sex difference in $\mathrm{HbA}_{1 \mathrm{c}}$ values in the diabetic group was observed in patients both under 40 (when women might be expected to be menstruating) and over 50; and this difference was not affected by the type of antidiabetic treatment given. $\mathrm{HbA}_{1 \mathrm{c}}$ values were also higher in the women diabetics irrespective of their body weight and blood glucose concentrations at the time of sampling.

\section{Comment}

These results draw attention to a difference in $\mathrm{HbA}_{1 \mathrm{c}}$ concentrations between diabetic men and women and the need for caution when blood glucose concentrations than the men. This would suggest that "female" haemoglobin can undergo a greater degree of glycosylation compared with that of male diabetic patients at the same blood glucose concentrations, and experiments to test this hypothesis are in hand.

1 Stickland MH, Perkins CM, Wales JK. The measurement of haemoglobin $A_{1 c}$ by isoelectric focusing in diabetic patients. Diabetologia 1982;22:315-7.

Goldstein DE, Parker M, England JD, et al. Clinical application of glycosylated hemoglobin measurements. Diabetes $1982 ; 31: 70-8$.

(Accepted 9 fuly 1984)

University Department of Medicine, General Infirmary, Leeds LS1 3EX

M H STICKLAND, HNC, technician

R C PATON, MD, MRCP, lecturer

J K WALES, MD, FRCP, senior lecturer 